社 説

\title{
Welcome, Nature Chemistry Nature Chemistryの創刊を微迎する
}

Nature Vol.458(680)/9 April 2009

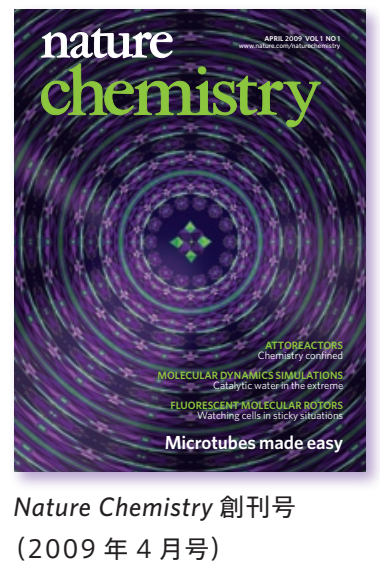

化学は科学の中核を成す一分野であるだけでなく、他の分 野とも密接に関連している。物理学の画期的な業績の数々 や高度な薬物療法の開発は、化学の原理と手法なくしては ありえなかっただろう。また、生物や環境についての我々 の理解も、化学からの重要な貢献なくしてここまで進むこ とはなかっただろう。

例を挙げればきりがない。21 世紀を生きる私たちが直 面している問題に取り組むためには、化学がもたらす新し いッール、材料、プロセスの力を借りる必要がある。効果 的で安価な薬物、代替エネルギー源や代替燃料、現代の技 術を向上させるスマート・マテリアルへの需要は大きく、 それを満たすためには、化学者の創造性、独創性、不屈の 努力が必要不可欠である。

幸い、化学研究コミュニティーは着実に成果を上げてい る。生物学や医学の分野で関心を寄せられている抏そろし く複雑な有機分子を巧妙、かつ効率よく合成する方法から、 環境にやさしく効率のよい工業プロセスを可能にする合理 的に設計された触媒まで、その成果は多岐にわたっている。 二酸化炭素の捕獲、太陽光を利用した有用な化学物質や工 ネルギーの生成、体内の狙った部位への薬物の送達と放出 など、機能を最適化するために分子レベルでの設計が試み られている材料は膨大な種類にのぼる。

その一方で、化学に基づくッールの種類も増えてきてお り、研究者は原子の空間的スケールと分子振動の時間的ス ケールで分子の構造と性質を探り、これらが関与するプロ セスを調べられるようになってきた。さらに、理論家たち がもたらした高度な計算能力とシミュレーション能力は、 質の高いデータを分子の相互作用、性質、プロセスに関す る詳細な微視的描像へと翻訳することを可能にし、これら の技術的進歩を一層充実させ、興味深いものにした。

ネイチャー・パブリッシング・グループ (NPG) が 2009 年 4 月に 15 番目のリサーチ誌である Nature Chemistryを
創刊することになった背景には、以上のような認識がある (最初のリサーチ誌は 1992 年に創刊された Nature Genetics である)。

Nature の他のリサーチ誌と同じく、Nature Chemistry の編集者は、刺激的な科学的知見を読者に紹介するだけで なく、有益な解説と議論の場を提供することをめざしてい る。それと同時に、インターネットを活用することで、従 来の印刷版の学術誌にはできなかった方法により科学的情 報を発表していく予定である。例えば、それぞれの論文は、 そこで論じられている化合物に関する情報（化学構造の双 方向三次元モデルなど）を含むページにリンクされている。 また、論文の本文中に出てくる化合物には番号がふつてあ り、数字の上にカーソルをのせると、化学構造を示すポッ プアップ・ウィンドウが出るようになっている。

Nature Chemistry は化合物識別機能も採用する。これ は、インターネットを利用して化学物質を検索できるよう にすることで、化学に関する情報に包括的、かつ効率よく アクセスできるょうにし、化学者間のコミュニケーション の一助とするためである。これらの機能は今後、Nature 本誌および他の姉妹誌でも採用していく予定である。

もちろん、Nature 本誌は今後も、化学の分野に重大か つ広範な影響を及ぼす論文や、特に興味深い応用可能性の ある論文を発表し続ける所存である。他の分野のリサー チ誌での経験から判断して、Nature Chemistry の創刊は、 化学分野に拈けるNature 本誌の影響力を強め、その範囲 を広げるのに間接的に役立つはずだ。Nature 本誌として も、メディアに関する高度の専門知識を駆使して、両誌に 発表される刺激的な化学的知見に触れられるようにするつ もりである。

現在、www.nature.com/naturechemistryにて Nature Chemistry 創刊号を無料公開中である。 